\title{
Sustainable Business Models in a Challenging Context: The Amana Katu Case
}

\author{
Modelos de Negócios Sustentáveis em Contextos Desafiadores: O caso \\ Amana Katu
}

\author{
José Augusto Lacerda Fernandes ${ }^{10}$ \\ José Milton de Sousa-Filho ${ }^{20}$ \\ Fernando Luiz Emerenciano Viana ${ }^{2}$
}

\section{ABSTRACT}

Context: the Brazilian Amazon region has the largest hydrographic basin in the world. However, even with such abundance, a good part of the population does not have access to quality water in their daily lives. In order to change that reality, a social business called Amana Katu created an innovative sustainable business model based on the principles of circular economy, built through partnerships with NGOs, corporations, government, and universities. Objective: this study aims to understand how sustainable business models can be co-created in challenging contexts. Methods: based on a qualitative case study, data was collected in three phases, from primary and secondary sources over three years, and analyzed following content analysis procedures. Results: the business model is based on different principles of circular economy, and the business cocreation process, based on partnerships with different stakeholders, was fundamental for the generation of value and impact associated with the three dimensions of sustainability. Conclusions: these results contribute to theory for a better understanding of the creation and development of SBMs in challenging contexts. In this kind of context, co-creation processes and a deep relationship with stakeholders have a unique function, and collaborate to create successful initiatives.

Keywords: sustainable business models; circular economy; challenging context; co-creation; Amazon.

1. Universidade Federal do Pará, Agência de Inovação Tecnológica (UNIVERSITEC), Belém, PA, Brazil. 2. Universidade de Fortaleza, Programa de Pós-Graduação em Administração de Empresas, Fortaleza, CE, Brazil.

Cite as: Fernandes, J. A. L., Sousa-Filho, J. M. de, \& Viana, F. L. E. (2021). Sustainable business models in a challenging context: The Amana Katu case. Revista de Administração Contemporânea, 25(3), e200205. https://doi.org/10.1590/1982-7849rac2021 200205.en

\section{RESUMO}

Contexto: a Amazônia brasileira possui a maior bacia hidrográfica do mundo. Contudo, mesmo com toda essa abundância, boa parte da sua população não tem acesso a água de qualidade no dia a dia. Para mudar essa realidade, um negócio social chamado Amana Katu criou um modelo de negócio sustentável e inovador baseado nos princípios da economia circular, e construído por meio de parcerias com ONGs, empresas, governo e universidades. Objetivo: este estudo procura compreender "Como modelos de negócios sustentáveis podem ser cocriados em contextos desafiadores?". Métodos: por meio de um estudo de caso qualitativo, foram explorados dados primários e secundários ao longo de 3 anos, analisando-os de acordo com procedimentos de análise de conteúdo. Resultados: o modelo de negócio se alicerça em diferentes princípios da economia circular e em processos de cocriaçáo, baseados em parcerias com diversos stakeholders, que foram fundamentais para a geraçáo de valor e impactos associados às três dimensóes da sustentabilidade. Conclusáo: esses resultados proporcionam contribuiçôes teóricas que alargam o entendimento sobre a criação e o desenvolvimento de SBMs em contextos desafiadores. Neste tipo de contexto, processos de cocriaçáo e de relacionamento profundo com os stakeholders têm uma função ímpar, e colaboram para a concretização de iniciativas bem sucedidas.

Palavras-chave: modelos de negócios sustentáveis; economia circular; contextos desafiadores; cocriação; Amazônia.

\begin{tabular}{|c|c|c|c|c|c|c|c|c|c|}
\hline & 1 & 2 & 3 & 4 & 5 & 6 & 7 & 8 & 9 \\
\hline $1^{\text {st }}$ round & $\stackrel{\varphi}{2}$ & $\stackrel{\varphi}{2}$ & & & & & & & \\
\hline $2^{\text {nd }}$ round & & $x$ & & & & & & & \\
\hline $3^{\text {rd }}$ round & E & & & & & & & & \\
\hline
\end{tabular}
Associate Editor: Elin Oftedal (University of Stavanger, Norway) (1) Reviewer: Tahrir Jaber (The Artic University of Norway, Norway) (a) One of the reviewers chose not to disclose his/her identity.
Ontric Jaber (The Artic Unity of Norway, Norway) One of the reviewers chose not to disclose his/her identity.
Peer Review Report: The Peer Review Report is available at this external URL. 


\section{INTRODUCTION}

The Brazilian Amazon region has the largest hydrographic basin in the world, with $25,000 \mathrm{~km}$ of navigable water, $20 \%$ of all liquid fresh water on the planet, and more than 1,000 rivers, among which the Amazon, the largest river in the world both in flow and in extension. However, even with such abundance, a good part of the population does not have access to quality water in their daily lives. Here is the paradoxical reality in the Amazon, a region of superlatives, and millions of people who live a daily life marked by the lack of a basic right and a vital good to human life: water (Aragón \& Clusener-Godt, 2003).

This context has daily exposed more than 10 million people to the risk of inadequate water supply (Sistema Nacional de Informaçóes sobre Saneamento [Snis], 2016) and has caused alarming rates of infant mortality in the Amazon: annually, only diarrhea caused by drinking contaminated water kills more than diseases like AIDS, measles, and malaria together (World Health Organization, 2017). It is a difficult situation to reverse and, therefore, quite challenging, due to several social problems characteristic of the region, such as extreme poverty, increasing deforestation, and lack of effectiveness of the public power, among others (Aragón, 2013).

In 2017, in order to change that reality and aiming to mitigate the clean water problem in that region, a social business called Amana Katu created an innovative sustainable business model in Brazilian Amazon. Amana Katu, which means 'good rain' in Tupi Guarani (a local indigenous dialect), has been taking advantage of the high rainfall in the region (Veloso \& Mendes, 2014) that still exists despite deforestation and climate change (Lovejoy \& Nobre, 2018), to offer an innovative and sustainable low-cost solution. The solution is a compact rainwater catchment system that promises not only to universalize access to water in the Amazon region, but also to avoid inconvenience caused by flooding in the urban space.

With a sustainable business model based on the principles of circular economy, and built through partnerships with NGOs, corporations, government, and universities, Amana Katu has obtained significant recognition from its stakeholders. Since it was designed in 2017 to participate in a competition of ideas and projects promoted by a university, Amana Katu has received a dozen national and international awards, highlighting the achievement of the World Water Race in Silicon Valley in 2018 , and, currently, its rainwater system provides access to clean water to over 7,000 people in Amazon region.

This case study addresses some gaps in the literature. First, understanding of sustainable business models and the options available for innovation for sustainability seems limited, and examples are focused on specific and big corporations (Bocken, Short, Rana, \& Evans, 2014). Second, most research in sustainable business models have investigated corporations in developed countries, giving less attention to nascent business in emerging markets. And third, the creation and development of a sustainable business model in a challenging context, such as the Brazilian Amazon conditions. Regarding literature gaps and context, our research question is: How sustainable business models can be co-created in challenging contexts?

Literature about innovative and sustainable business models (Bocken et al., 2014; Chesbrough, 2010; Teece, 2010) and some principles of circular economy (Ghisellini, Cialani, \& Ulgiati, 2016; Geissdoerfer, Savaget, Bocken, \& Hultink, 2017) were used to describe and analyze the case and its main results. Therefore, this qualitative case study aims to investigate how sustainable business models can be co-created in a challenging context.

We collected data from primary and secondary sources over three years. Primary sources were in depth interviews with entrepreneurs, and observations with stakeholders that help co-create the solution. Secondary data were collected with available documents (managerial reports, media reports, videos, and public presentations).

Results can be summarized in some topics: (a) the business model is based on different principles of circular economy; (b) the establishment of less obvious partnerships with actors from other sectors, such as the food industry, has been fundamental for a value proposal offered; (c) the business co-creation process, based on partnerships with different stakeholders, was fundamental for the generation of value and impact associated with the three dimensions of sustainability - environment, social, and economic (Elkington, 1994).

In conclusion, Amana Katu used co-creation process and circular economy principles in order to design, develop, and implement a successful sustainable business model that affects many people that do not have access to clean water.

We divide the article into six sections. After this introduction, we present the theory with literature about sustainable business models and circular economy, where we developed the theoretical framweork, followed by method. Fourth section presents the case study, followed by discussion and conclusion.

\section{THEORY}

Despite the challenges of the Amazon region, civil society and some organizations (public, private, and third sector) are investing time and other resources in order to alleviate those problems and mitigate its negative effects. 
Theories about sustainable business models and circular economy practices have been used in the literature, trying to explain how some initiatives could positively affect society. In this line, we have used these topics in the following literature review.

\section{Sustainable business models (SBMs)}

According to Lüdeke-Freund and Dembek (2017), the business model concept has become very prominent over the past 15 years in both research and practice, and researchers dealing with sustainable development, sustainability, and corporate social responsibility started to explore whether and how the business model concept can be used to investigate business-based solutions for social and environmental problems. The connection among business model and the literature on sustainable aspects culminated in the sustainable business model (SBM) literature.
Schaltegger, Lüdeke-Freund, and Hansen (2016) affirm that a SBM "helps describing, analyzing, managing, and communicating (a) a company's sustainable value proposition to its customers, and all other stakeholders, (b) how it creates and delivers this value, (c) and how it captures economic value while maintaining or regenerating natural, social, and economic capital beyond its organizational boundaries" (Schaltegger, Lüdeke-Freund, \& Hansen, 2016, p. 268). This notion is very important to understand the evolution of new and consolidated ventures that decide to engage in a business model related with sustainability aspects.

Lüdeke-Freund, Carroux, Joyce, Massa, and Breuer (2018), with a Delphi research design, found 45 patterns of SBM. These patterns were grouped into 11 categories and can be viewed on Table 1 .

Table 1. Sustainable business models categories.

\begin{tabular}{|c|c|}
\hline Category & Definition \\
\hline Pricing \& Revenue & Patterns that primarily address the revenue model of a business model. \\
\hline Financing & Patterns that address the financing model within a business model. \\
\hline Ecodesign & Patterns that integrate ecological aspects into key activities and value propositions. \\
\hline Closing-the-Loop & $\begin{array}{l}\text { Patterns that help integrate the idea of circular material and energy flows into partnerships, key activities, and customer } \\
\text { channels. }\end{array}$ \\
\hline Supply Chain & $\begin{array}{l}\text { Patterns that modify the upstream (partners, resources, capabilities) and/or downstream (customers, relationships, channels) } \\
\text { components of a business model. }\end{array}$ \\
\hline Giving & Patterns that help donate products or services to target groups in need. \\
\hline Access Provision & $\begin{array}{l}\text { Patterns that create markets for otherwise neglected target groups, involving modified value propositions, channels, revenue, } \\
\text { pricing and cost models. }\end{array}$ \\
\hline Social Mission & $\begin{array}{l}\text { Patterns that integrate social target groups in need, including otherwise neglected groups, either as customers or as productive } \\
\text { partners. }\end{array}$ \\
\hline Service \& Performance & Patterns that emphasize the functional and service value of products and that offer performance management. \\
\hline Cooperative & $\begin{array}{l}\text { Patterns that integrate a broad range of stakeholders as co-owners and co-managers, how partners are defined and how the } \\
\text { organization is governed. }\end{array}$ \\
\hline Community Platform & $\begin{array}{l}\text { Patterns that substitute resource or product ownership with community-based access to resources and products, how value } \\
\text { propositions are defined and delivered. }\end{array}$ \\
\hline
\end{tabular}

These different patterns give to the SBM phenomena huge possibilities of analysis, including different classifications and associations with distinct value creation processes. SBMs have great potential to incorporate the principles of sustainability and integrate sustainable goals into the value proposition, value creation, and value capture activities (Boons \& Lüdeke-Freund, 2013; Nosratabadi et al., 2019).
In general, value creation is the central aspect of any business model research (Freudenreich, Lüdeke-Freund, \& Schaltegger, 2020; Richardson, 2008; Wirtz, Pistoia, Ullrich, \& Göttel, 2016; Zott, Amit, \& Massa, 2011). Value creation in SBM literature has received important attention because of its intrinsic potential to create social and environmental value, and to spread this value to society. 
Value creation for society demands to understand the importance of stakeholders (customers, employees, community, suppliers, and business partners, among others) in the process. The prevalent approach in the SBM literature considers that value creation is a process resulting in different outcomes for different stakeholders (Bocken, Short, Rana, \& Evans, 2013; Lüdeke-Freund \& Dembek, 2017; Schaltegger et al., 2016). SBM positively influences businesses to integrate their economic objectives with their sustainability ambitions in such a way that the benefits of all the stakeholders are achieved simultaneously (Rashid, Asif, Krajnik, \& Nicolescu, 2013). Nosratabadi et al. (2019)found that SBMs offer solutions, such as designing a market-oriented business model to provide winwin solutions for multiple stakeholders.

Regarding the importance of the role of stakeholders in value creation by SBMs, Freudenreich, Lüdeke-Freund, and Schaltegger (2020) developed a framework for stakeholder value creation, because these authors consider relationships as a key element of business models. In general, business models should be designed, developed, and realized in relationships between a business and its stakeholders (Freudenreich et al., 2020), and in a SBM the involvement of different stakeholders tends to be stronger. Yet, Freudenreich et al. (2020) affirm that a further central element is a joint purpose behind which stakeholders engage in a SBM.

Evans et al. (2017) offer some theoretical propositions about SBMs, and part of them was about value creation and stakeholders. For example: (a) SBMs require a system of sustainable value flows among multiple stakeholders, (b) SBMs require a value network with a new purpose, design and governance, and (c) SBMs require a systemic consideration of stakeholder interests, and responsibilities for mutual value creation. The aspect of value creation through and with stakeholders is a central characteristic of SBMs. From this relation emerges the conversation about co-creation with stakeholders.

The co-creation with stakeholders enables the power of networks and creates more suitable and feasible solutions in order to create value for multiple stakeholders, and can be implemented in different design approaches. The bottom of the pyramid is the main approach for designing SBMs in developing countries (Nosratabadi et al., 2019), including co-creation initiatives with communities. Co-creation process can be developed in a diverse base, including formal and informal partnerships with customers, suppliers, and community, among others. At this point, has emerged as interesting experiences of co-creation propositions the multi-stakeholders initiatives and the circular models.

SBM has emerged to provide a platform for integrating sustainability aspects, and from this perspective, circular business models are similar to SBM (Nosratabadi et al., 2019). Circular economy is clearly a kind of SBM, and sustainable business models that adopt circular economy principles are commonly called circular business models (Bocken, Pauw, Bakkerd, \& Grinten, 2016; Jabbour et al., 2019). As SBMs, circular business models function as a way to reduce social and ecological impacts or even as a way to purposefully achieve sustainable development (Boons \& Lüdeke-Freund, 2013). Next section provides more explanation about circular economy literature.

\section{Circular economy}

Circular economy is an economy constructed from societal production-consumption systems that maximizes the service produced from the linear nature-society-nature material and energy throughput flow. This is done by using cyclical materials flows, renewable energy sources, and cascading-type energy flows. Successful circular economy contributes to all the three dimensions of sustainable development. Circular economy limits the throughput flow to a level that nature tolerates and utilizes ecosystem cycles in economic cycles by respecting their natural reproduction rates (Korhonen, Honkasalo, \& Seppälä, 2018).

The circular economy (CE) is a system of production and consumption that aims to keep products, components, materials, and energy in circulation in order to continue adding, recreating, and maintaining their value over a long period (Jabbour et al., 2019). CE is a regenerative system in which resource input, waste emission, and energy leakage are minimized by slowing, closing, and narrowing material and energy loops. This can be achieved through longlasting design, maintenance, repair, reuse, remanufacturing, refurbishment, and recycling (Geissdoerfer et al., 2017).

The definition of Geissdoerfer, Savaget, Bocken, and Hultink (2017) presents some principles that are the basis of the circular economy business models. Circular product design and business models can enable economically viable ways to continually reuse products and materials, using renewable resources where possible, and have to be directed toward two fundamental strategies for the cycling of resources (Bocken, Pauw, Bakkerd, \& Grinten, 2016, p. 309): (a) Slowing resource loops, where through the design of longlife goods and product-life extension (i.e., service loops to extend a product's life, for instance through repair, remanufacturing), the utilization period of products is extended and/or intensified, resulting in a slowdown of the flow of resources; (b) Closing resource loops, where through recycling, the loop between post-use and production is closed, resulting in a circular flow of resources.

Circular economy incorporates a variety of practices or principles based on the circular flow of materials that 
can be used in multiple production instances, and are based upon waste minimization and increased product utilization at post-stages (Batista, Gong, Pereira, Jia, \& Bittar, 2019). Based on the literature (Ghisellini et al., 2016; Murray, Skene, \& Haynes, 2017), we consider six principles as representatives of the circular economy business models, which are presented in Table 2 .

Considering the wide field of action, there are many opportunities for the implantation of $\mathrm{CE}$ through its principles. However, there are some challenges and limitations to be overcome (Korhonen et al., 2018). One of them is the lack of an effective social approach (Murray et al., 2017), which is very important from a sustainability perspective.
The social dimension ends up being 'forgotten' by the CE defenders, either due to the difficulty of integrating it with the network components or even due to the low level of development of the CE in a business environment, considering that its evolution is slow in relation to others organizational sustainability models (Matews \& Tan, 2011). The focus in the social dimension is even more important in emerging economies, which use to have many social problems to be solved.

Therefore, we understand that initiatives such as the implementation of sustainable business models based on the principles of circular economy, which bring social benefits in developing countries, are extremely relevant.

Table 2. Circular economy principles.

\begin{tabular}{ll}
\hline \multicolumn{1}{c}{ Principle } & \multicolumn{1}{c}{ Definition } \\
\hline Ecodesign & $\begin{array}{l}\text { It emphasizes the importance of the design stage in the search for solutions to avoid the discharge of waste in landfills. Products are } \\
\text { designed for a disassembly and reuse cycle. }\end{array}$ \\
\hline Reduction & $\begin{array}{l}\text { It aims to minimize the entry of energy, raw materials, and waste by improving efficiency in production processes and consumption, } \\
\text { for example, by introducing better technologies, lighter or more compact products, simplified packaging, etc. }\end{array}$ \\
Reuse & $\begin{array}{l}\text { It assumes that products or components that are not waste are used again for the same purpose for which they were designed. } \\
\text { Recycling }\end{array}$ \\
$\begin{array}{l}\text { Recovery operation through which waste is processed into products, materials, or substances, whether for original use or for other } \\
\text { purposes. It allows continuity in the circulation of components and materials in the economic system, extending the use of these } \\
\text { materials to the maximum. }\end{array}$ \\
$\begin{array}{l}\text { It introduces a reclassification of materials into 'technicians' and 'nutrients'. Technical materials (such as metals and plastics) are } \\
\text { designed to be reused at the end of the life cycle, while biological nutrients, which are generally non-toxic, can safely return to the } \\
\text { biosphere. }\end{array}$ \\
$\begin{array}{l}\text { It places renewable energies as the main source of energy for the circular economy, reducing the dependence on fossil energy and } \\
\text { improving the adaptability (resilience) of the economic system in relation to the negative effects of oil. }\end{array}$ \\
\hline
\end{tabular}

\section{Theoretical framework}

Based on the prior literature about SBM and CE, we propose a theoretical framework that explains how these principles interact and how they can be applied to satisfy the demands of different stakeholders, some of whom can participate in the co-creation process and benefit from the value delivered. Figure 1 presents the theoretical framework.

The framework is based on some main assumptions. First, circular economy, represented by its principles (ecodesign, reduction, reuse, recycling, reclassification, and renovation), is a special type of SBM (Bocken et al., 2016; Jabbour et al., 2019).

Second, sustainable business models should make explicit their value proposition to the customers and all other stakeholders, how they create and deliver value (value creation), and how they capture economic value (value capture) (Schaltegger et al., 2016).
Third, stakeholders are essential at all stages of the SBM business cycle. Some stakeholders (for example, consumers, NGOs, governments) have demands to be satisfied by the products and services offered by SBM. Other stakeholders (for example, suppliers, components of the innovation ecosystem - universities, researchers) actively participate in the co-creation process. Finally, other stakeholders (customers, society in general) benefit from the delivery of value from SBMs, especially the economic, environmental, and social benefits associated with the products and services delivered.

This framework seeks to represent the logic of SBM in general, with emphasis on circular business models. From the specifics of each SBM, as well as the reality of the context in which they are inserted, it is possible to adapt the framework and highlight the elements that stand out. 


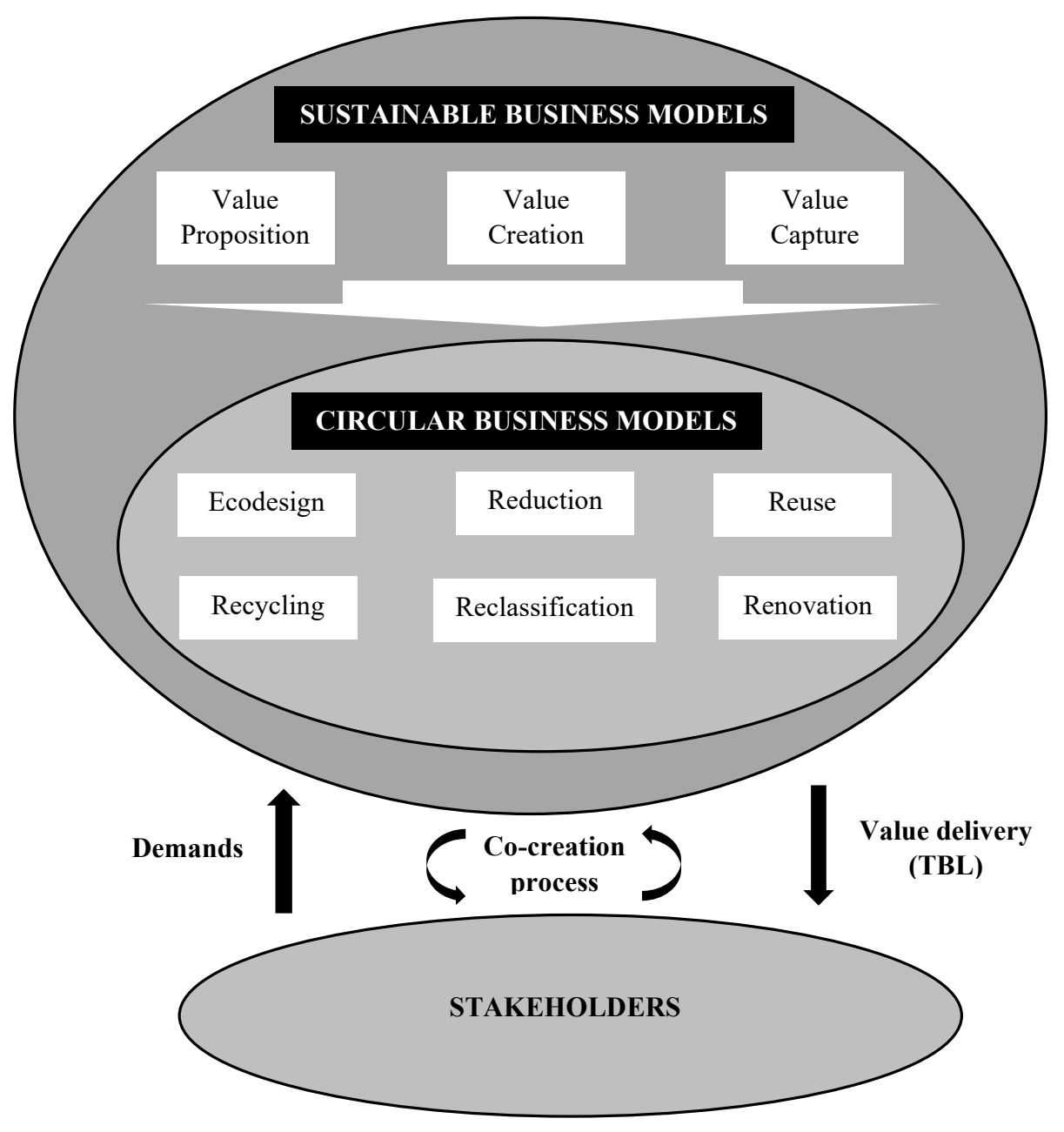

Figure 1. An integrative view between SBM, CE, and stakeholders.

\section{METHOD}

This paper elaborates theory on sustainable business models (SBMs), the role of circular economy principles in SBMs, and their relationship with stakeholders. Theory elaboration focuses on the contextualized logic of a general theory and can introduce new concepts, conduct an indepth investigation of the relationships among concepts, or examine boundary conditions (Ketokivi \& Choi, 2014).

We began proposing a theoretical framework (Figure 1) based on the main aspects of SBMs and principles of CE. After, we adopted an inductive perspective by using observations based on a qualitative case study (Yin, 2014) and a longitudinal approach (Cooper \& Schindler, 2016) to elaborate theory (Ketokivi \& Choi, 2014), related to understanding the process of co-creating sustainable business models in challenging contexts.
The choice of the case was guided by its adherence to the approaches of sustainable business models, which serves the purposeful sampling based on theory (Patton, 2014), as well as the accessibility to conduct the research. The accessibility is inherent to the involvement of one of the researchers in the entire process of evolution of the social enterprise that makes up the case. Therefore, we carried out a case study of the social business Amana Katu, an undertaking originated approximately three years ago with the ambitious aim of universalizing access to quality water in the Amazon.

Data collection on the case was divided into three phases, using different data sources. In the first phase, we sought to gain a broader understanding of the genesis and evolution of the enterprise, using documentary sources that were not susceptible to the inaccuracies typical of retrospective approaches: reports made about the initiative in different media, including TV reports, newspapers, 
magazines, and blogs; institutional videos; social networks; annual reports and internal files (provided by the business partners themselves) to reconstruct the sequence of events that marked the process of building the business model. After all, developing a process-based approach to social entrepreneurship can be of great value in understanding how certain initiatives develop, from the stage when they are just ideas to the moment when they are profitable businesses with high scalability potential (Perrini, Vurro, \& Costanzo, 2010).

In the second phase, in order to learn more about the context and the challenges related to the construction of the business in each phase of its trajectory, different types of observation were used, participant and non-participant (Cooper \& Schindler, 2016). Such an approach was vital to understand the interpretations and meanings attributed by the entrepreneurs to some remarkable events as well as criticisms received about the business model along its development.

Finally, due to the need to elucidate some specific points about the co-creation processes existing in this trajectory, we carried out a set of in-depth interviews with different subjects in the third phase. Such a procedure has the ability to capture phenomena that are episodic and infrequent (Eisenhardt \& Graebner, 2007), which was extremely important to counter the findings obtained so far. Even more when one considers that the corpus of respondents was integrated by subjects with a high degree of involvement with the initiative: people who, directly or indirectly, participated in the creation, development, and management of the enterprise over the past three years, with prominence obvious to their current partners. Then, we conducted the interviews with the entrepreneurs of Amana Katu, the leader of the Enactus UFPA project, professors from the partner university - Universidade Federal do Pará (UFPA), managers from partner organizations (Amanco Wavin, Mariza Foods, and ONG Emaús), manager of the Enactus Brasil network, manager from the UFPA innovation agency, mentors of the project during its development, and evaluators of accelerator program, totaling 16 respondents.

To do the interviews, we used a semi-structured script, containing open questions related to the research objective and the categories of analysis presented in Table 3 , which presents the main information related to each of the phases mentioned.

Table 3. Phases of the data collection.

\begin{tabular}{|c|c|c|c|c|}
\hline Phase & Objective & Categories of analysis & Data source & Participants \\
\hline First & $\begin{array}{l}\text { To understand the genesis and } \\
\text { evolution of the enterprise }\end{array}$ & $\begin{array}{l}\text { SBM evolution; } \\
\text { The role of stakeholders and } \\
\text { partnerships }\end{array}$ & $\begin{array}{l}\text { Documents: reports, } \\
\text { institutional videos, social } \\
\text { networks, internal files }\end{array}$ & $\mathrm{N} / \mathrm{A}$ \\
\hline Second & $\begin{array}{l}\text { To learn about the context and } \\
\text { the challenges related to the } \\
\text { construction of the business in } \\
\text { each phase of its trajectory }\end{array}$ & $\begin{array}{l}\text { Characteristics and challenges of } \\
\text { the context }\end{array}$ & $\begin{array}{l}\text { Participant and non-participant } \\
\text { observations }\end{array}$ & Author 1 \\
\hline Third & $\begin{array}{l}\text { To elucidate some specific points } \\
\text { about the co-creation processes }\end{array}$ & $\begin{array}{l}\text { SBM evolution; } \\
\text { Principles of circular economy; } \\
\text { Co-creation processes }\end{array}$ & Interviews & $\begin{array}{l}3 \text { Amana Katu entrepreneurs; } \\
2 \text { professors from UFPA; } \\
1 \text { Enactus UFPA leader; } \\
3 \text { managers of partner } \\
\text { organizations; } \\
1 \text { manager of Enactus Brazil; } \\
1 \text { manager of UFPA's } \\
\text { Innovation Agency; } \\
3 \text { project mentors; } \\
2 \text { accelerator program evaluators }\end{array}$ \\
\hline
\end{tabular}

Some topics addressed by the interview script were: (1) Main milestones in the business history; (2) Effects of the contact with the community; (3) Key competitions and mentoring processes over the course of the business; (4) Interactions and cooperation with stakeholders; (5) Main problems and mistakes along the business path; (6) Key business model partners; (7) Current stage of the business model; (8) Adherence to the principles of circular economy; (9) Dynamics of the co-creation process. Other questions arose during the interviews, from the responses of the interviewees, especially due to their different profiles.

Thus, the research used different data collection procedures to reconstruct, in a rigorous and systematic way, 
the trajectory of the business model of the studied enterprise, from its idealization, in mid-2017, until the beginning of 2020. This data collection process was of fundamental importance to understand how the phenomenon occurred, generating an in-depth understanding and the reach of theoretical and practical contributions. In addition, the evidence obtained through multiple data sources, allowing different voices to be compared and ambiguities and biases to be mitigated, includes the practice of triangulation, one of the fundamental principles to be followed to give greater robustness to the results of case studies (Yin, 2014).

After collecting data and preparing the material (for example, transcribing the interviews), the data were analyzed using a system of codes to explore the collected material. This system of codes was based on the theoretical aspects used for the analysis of the cases, including the sustainable business model, the co-creation processes and the principles of the circular economy, which are among the categories of analysis defined a priori (see Table 3). This coding and analysis process followed the content analysis procedures proposed by Bardin (2016).

We use a software for qualitative data analysis, Atlas. ti (Paulus \& Lester, 2016), to support the data analysis process, keeping the creative and intellectual tasks under the responsibility of the researchers. We use the chain of evidence from different sources to further explore the elements of interest in the case.

\section{CASE DESCRIPTION}

\section{Trajectory: From an idea to a social business}

Amana Katu is a social business for universal access to water in the Amazon, made possible through sustainable rainwater harvesting technology. This initiative came about in mid-2017, when a group of students decided to participate in a university competition for innovative ideas and projects to address a socio-environmental issue in the region, called Desafio Inove+ 2017. At this moment, the context in which the inhabitants of the largest hydrographic basin in Brazil live, which constitutes a striking contrast between the abundance and scarcity of water, drew the attention of the students. Therefore, they decided to propose a solution aimed at this problem.

The team developed a system where water is captured through a gutter installed on the roof of each house and stored in reservoirs of up to 240 liters (Figure 1). By means of different filtering layers, the system is able to provide quality water to communities that used water withdrawn directly from the river, running a series of health risks, or that paid a high price to purchase mineral water.

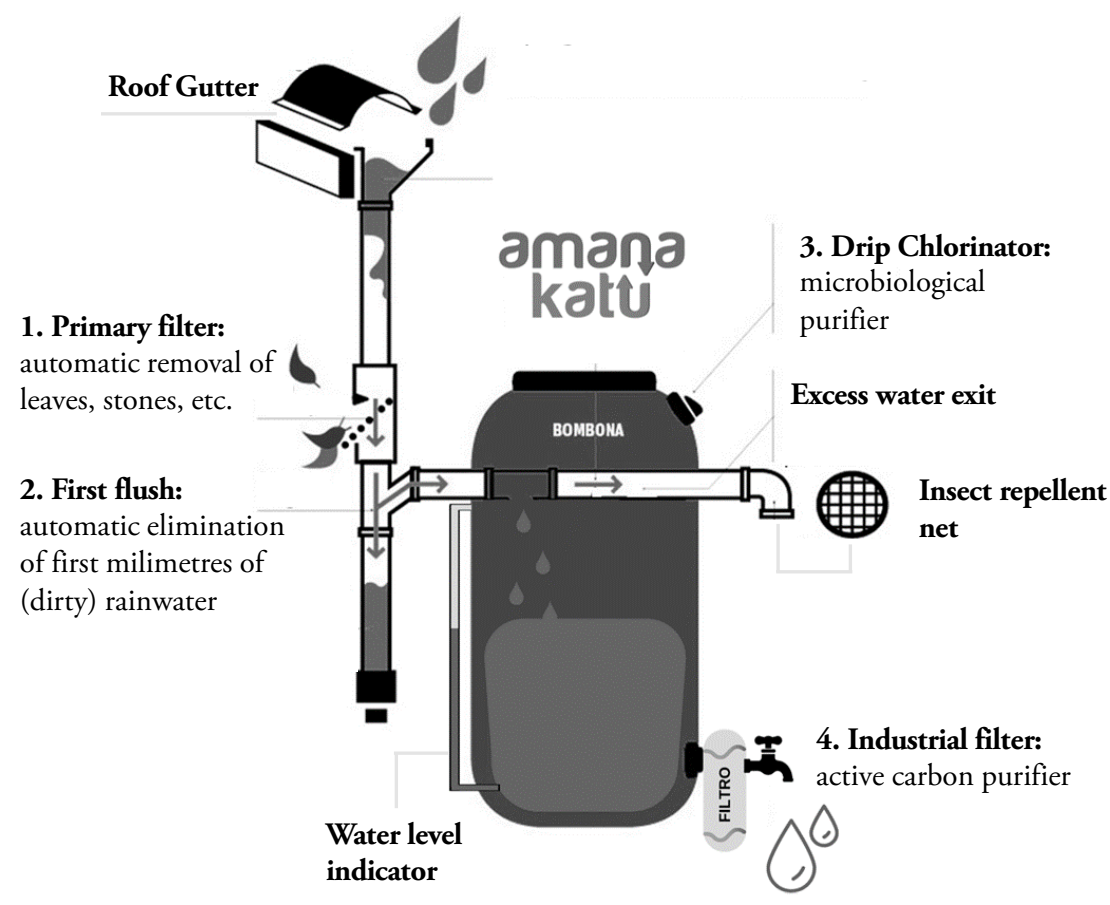

Figure 2. Amana Katu product.

Image provided by Amana Katu. 
The system needs that the catchment cisterns, roofs, and gutters undergo periodic cleaning, and that the water quality is monitored to guarantee its potability. As a result, the team implemented a complementary action to train users, not only on the functioning and characteristics of the system, but also on health issues in a broader sense, through environmental education actions.

So, the solution can be characterized as a multidimensional intervention aligned with the notion of health promotion, in line with the Ottawa Charter principles, which emphasizes the responsibility and rights of individuals and the community for their own health, including greater participation in controlling this process (World Health Organization, 1986).

\section{Achievements}

Amana Katu has participated in several events, organized by different types of institutions, with the purpose of refining its business model and raising funds to leverage its socio-environmental impact, obtaining recognition and awards in several of them (Appendix A). We can highlight the Ford Mobility Innovation Challenge, World Water Race, AB InBev Accelerator Program, and the Global Competition of Green Business Ideas by Climate Ventures.

Through the prizes obtained with these international awards, Amana Katu managed to install an expressive number of 225 cisterns in different locations in the Amazon, bringing quality water to approximately 7,650 people and generating savings of 232,000 Reais ( $R$ \$) in medicines. In addition, each episode of this one generated significant experiences in the sense of generating meaningful learning and cooperation ties with different actors (Dimov, 2007).

\section{Partnerships and stakeholders}

An important factor for the business model development was the set of partnerships formed with various actors, such as the university that started the initiative, the Federal University of Pará (UFPA), where Amana Katu team studied. The initiative was developed as one of the Inove+ Challenge projects, a competition of ideas and projects promoted by UFPA.

After this period, Amana Katu became one of the projects of the Team Enactus UFPA, being developed within the scope of the Enactus Network, an international organization that works with students and universities in 37 different countries.

Expressive results achieved by Amana Katu in terms of awards (Appendix A) denote the existence of a close relationship between the role of the Enactus Network and other intermediary organizations (of the social impact ecosystem) in advancing the initiative, which allowed access to financial resources that enabled a greater reach of the initiative (thousands of people).

However, the role of these organizations is not limited to offering awards and financial resources. According to the analyzed documents and interviews, university challenges, hackathons, and experience acceleration programs were vital for team members to be able to access people, another decisive factor for the evolution of the business model, and that was able to 'shorten the path' to the market.

One of the valuable collaborations came from an action together with the company Amanco Wavin, which with its expertise in the segment (sanitary, water and housing) started to donate some inputs and give advice on the installation process of the gutters and pipes necessary to direct rainwater (from the roofs) to the entrance to the cisterns.

In any case, there was still a challenge that afflicted entrepreneurs and made the business model unviable in financial and operational terms: the cost and regular supply of the cistern, the main input of the production process. The solution for this came through a partnership with a large food company in the region, which started to donate, monthly, $240 \mathrm{~L}$ containers previously used to transport olives from Chile to the state of Pará, in Brazil. Known as 'bombonas,' these containers did not have any reverse logistics mechanism because of the inherent cost of displacement (from practically all of South America), therefore remaining as one of the many wastes generated by such industry. Thus, the partnership made the business model even more sustainable, because in addition to addressing a social issue, it also began to mitigate an environmental issue. This was a key partnership with an important stakeholder in the process, using a circular model.

The cooperation with the food company was idealized and mediated by a professor from the university who had contacts in that industry. This, in addition to reinforcing the thesis that cooperation ties between organizations are strongly linked to cooperation ties between individuals (Jamali, Yianni, \& Abdallah, 2011), demonstrates the university's influence on the evolution of the business model in question - not only in its genesis, but during several other moments of its development.

\section{Business model}

Initially, the business turned its attention solely to direct sales to people who suffered from a lack of quality water in their homes (B2C). However, the project subsequently turned its efforts to also serve another public, of a corporate scope (B2B), with the objective of sensitizing companies so that they would make acquisitions in large quantity, destining part of the quantity to people in situation of vulnerability, who 
have very low monthly income and therefore have difficulty purchasing the Amana Katu system.

By observing that the value of the system, in general, is equivalent to what families spend for four or five months with the purchase of mineral water, the entrepreneurs initially tried to articulate a system of installments that would make the acquisition of the system feasible. However, due to difficulties in accessing credit due to the absence of fixed income, many potential consumers did not have credit cards, bank checks, or other payment mechanisms of a future order. So, a mechanism was added to the business model that leveraged the donation of systems to those who really need it most and are unable to pay: the 5 for 1 system. From then on, regardless of donations from purchases made by local companies, Amana Katu itself began to donate, for every five units sold, one to those who cannot afford to buy the system.

In addition to promoting access to quality water, Amana Katu has contributed to the generation of income by vulnerable young people, so that its social impact is not only due to its basic activities, but also to its complementary activities. To this end, the business established a partnership with the Movimento República de Emaús, a nongovernmental organization (NGO) led by an Italian priest. This NGO has been working strongly with social causes for more than 50 years, such as the professionalization of young people with a history of family problems and/or juvenile delinquency. Thus, Amana Katu started to have not only a community to manufacture the systems, but also a space to store the 'bombonas' and assemble the systems.

In addition, the partnership certainly yielded learning gains for young entrepreneurs, given the history of the institution involved, and even of legitimacy, as several actors and vehicles of communication know the NGO. In any case, this does not mean that the partnership provided asymmetric gains. Judging by the continuity of the relationship, it is believed that the partnership had an expressive capacity to generate shared value for both involved.

This interaction between business leaders and users of the solution has been important to implement improvements in the system throughout its development. At different times, feedback obtained together with the communities led to incremental changes in the system, such as the implementation of filters that until then did not exist and that, after being added, ended up improving the quality of the water treatment.

The adoption of a business model that favors the donation of products to those who cannot pay for them, together with the aggregation of vulnerable young people, associates Amana Katu with an important characteristic of SBMs. According to Choi and Gray (2008), sustainable entrepreneurs are an unusual breed with limited business backgrounds. Business concepts originate from the founders' broad idealism and drive to make a small difference in the world. They find innovative methods for balancing their financial goals against their objectives of making a difference in their environment and society. Donating company profits and other resources was considered not an afterthought but an important function of business.

At the same time, given so much clear evidence of the plural importance of collaboration - with different actors and in different contexts - in the trajectory of Amana Katu, we can infer that the combination of different models of cooperation helps in the development of innovative solutions in response to major social and environmental challenges. Table 4 presents the main partners, its contributions and collaboration in the co-creation process of Amana Katu SBM.

Table 4. Main partners of the Amana Katu SBM.

\begin{tabular}{lll}
\hline Partner institution & Contributions & Co-creation in SBM \\
\hline University (UFPA) & $\begin{array}{l}\text { Specialized knowledge, physical } \\
\text { contacts, legitimacy. }\end{array}$ & $\begin{array}{l}\text { Creation of the value proposal, elaboration of the business } \\
\text { structure, network of }\end{array}$ \\
$\begin{array}{l}\text { MVP (minimum viable product), access to specific knowledge } \\
\text { on the use of rainwater, access to the network of actors and } \\
\text { communities benefited by the designed system. }\end{array}$
\end{tabular}

$\begin{array}{ll} & \text { Fundraising opportunities, knowledge about project } \\ \text { management with a socio-environmental focus, interaction } \\ \text { Enactus Network }\end{array} \quad \begin{aligned} & \text { with organizations from the innovation ecosystem, Enactus } \\ & \text { teams from Brazil and the world, and network contacts. }\end{aligned}$

Amanco Wavin Inputs and specific knowledge on hydraulics and other topics.

Mariza Foods Source of reused 'bombonas.'

NGO Emaús Qualification and training of vulnerable youth served by the NGO.

Accelerator programs
Obtaining capital to invest in the business and a series of lessons learned and developing solutions for internal processes (communication, financial management).

Improving system performance and increasing business competitiveness.

Decreased production cost.

Qualified labor to manufacture the systems.

Structuring B2B sales and gaining more knowledge about financial and logistics management. 
Another element that has played an important role in the operationalization of the business model resides in the corporate structure, composed by the entrepreneurs with different backgrounds: law student, master's student in civil engineering, biotechnologist. In line with Dufays and Huybrechts (2017), in addition to gathering different knowledge, the partners have been able to exercise well-defined roles and responsibilities in conducting the social business.

The importance of highly qualified leaders seems to have been another decisive factor for the trajectory of Amana Katu, directly interfering in activities that went from the prototyping of new technologies to the development of partnerships and fundraising, like the presentations made to large audiences and evaluation boards, in 2018 and 2019, in Silicon Valley, without which the project would not have been able to leverage an amount of capital that was fundamental for its expansion.

When expressing their perceptions about the three business partners, network managers and partners of the Enactus Brasil Network who were present at such events were unanimous about their qualifications, and it is common to register praise for their posture, in-depth knowledge of the topics, argumentative and relationship skills, interpersonal skills, and fluency in a foreign language.

In addition, the engagement of these leaders in other professional development opportunities has also been vital for the advancement of the project. In parallel with their performance in the scope of the initiative, the three current members of Amana Katu have been individually involved in other youth entrepreneurship programs, such as Pró-Líder and Ford ambassadors. From the interviews carried out, it is clear that this not only helped them acquire knowledge that came to be applied in the business, but also expanded their contact networks and propagated the enterprise in other spaces.

\section{DISCUSSION AND PROPOSITIONS}

The case description shows many important characteristics that can be analyzed by our theoretical framework (Figure 1). In this section, we discuss case results based on literature, and expand theoretical contributions with three propositions.

\section{Business model pattern combination}

Amana Katu works with a robust sustainable and circular business model with success in communicating its sustainable value proposition to customers and all other stakeholders, creating, capturing, and delivering value (Schaltegger et al., 2016). Based on the proposed framework, value proposition, value creation, and value capture are relevant aspects of SBM; without these points, any business model performs unsuccessfully.

Amana Katu is engaged in 7 of 11 SBM patterns (Lüdeke-Freund, Carroux, Joyce, Massa, \& Breuer, 2018), and the interaction of these patterns provides important differentials. Here we introduce the notion of pattern combination, which improves some aspects of any sustainable and circular business model, mainly establishing new forms of value proposition, creation, and capture, focusing on stakeholder needs. SBM patterns such as ecodesign, closing-the-loop, social mission, access provision, giving, cooperative, and community platform were used. Amana Katu has used the ecodesign principle (more discussion below), and additionally, we can affirm that closing-the-loop pattern is associated with its business model, because it tries to appropriate and integrate circular material coming from partners.

The patterns of social mission, access provision, and giving are highly associated with Amana Katu business model, as a social business that has a social-driven approach (social mission) aiming to make better the access to clean water (access provision), after donating the product to beneficiaries (giving). Thus, all of these patterns were discussed by Lüdeke-Freund et al. (2018), and make sense for Amana Katu's sustainable and circular business model. Based on these arguments, our first proposition follows:

Proposition 1: SBM pattern combination improves value proposition, creation, and capture in circular business models.

\section{Co-creation with stakeholders}

Amana Katu develops all of its processes with partners in a cooperative partnership, including community. This actor is really important in the process, because the community not only acts as a beneficiary, but built the product with Amana Katu. In this sense, it can be considered that, in certain contexts, as challenging contexts, collaboration with actors from other sectors can leverage the result in a very expressive way (Manning \& Roessler, 2014), even more when combined with partnerships with organizations directly involved with the core activity of the business. Moreover, the notion of challenging context needs to be improved in the literature, because prior and relevant literature about SBM and CE delivered less focus on challenging contexts. Thus, inserting this notion in the literature can be seen as a contribution to theory. Cooperative pattern (Lüdeke-Freund et al., 2018) emerges one more time when we analyze a wide list of partners of Amana Katu (Table 4), as corporations, NGOs, among others, and the value generated flows among these stakeholders (Evans et al., 2017). All of these 
stakeholders have some important role for the final impact (social, environmental, and economic) and with a purpose and governance (Evans et al., 2017) provided by Amana Katu, in conjunction acting as a life changing initiative. It is a finding that reinforces, in turn, the potential of impact investments in generating concrete transformations (Brest \& Bordn, 2013).

Such evidenceisin linewith theview that the emergence and the development of social business are strongly related to formal and informal networks, as well as the structure and culture of a community (Cohen, 2006). Formal networks like Enactus and informal networks developed in different contexts, and with multiple actors, leveraged the social impact of the business model built / adopted by Amana Katu. These aspects about relationship and co-creation with stakeholders, mainly regarding demands and value delivery, are covered by our theoretical model (Figure 1). Based on these arguments, our second proposition follows:

Proposition 2: Co-creation with stakeholders in challenging contexts expands demands and value delivery, at the same time that defines and improves value proposition, creation, and capture in SBM.

\section{Developing circular business models through stakeholder interaction}

In different phases of Amana Katu's trajectory, as well as in the product and in the business model, circular economy principles (Ghisellini et al., 2016; Murray et al., 2017) were applied. The first one is the principle of ecodesign, which premises the search for solutions to avoid the discharge of waste in landfills and develops products designed for a disassembly and reuse cycle (Ghisellini et al., 2016). The product (system of water treatment) has one fundamental component, the 'bombona,' that is a container previously used to transport olives, so the conception is based on a reuse cycle. In addition, the system was designed to collect and treat rainwater to make it drinkable, water that is usually wasted in homes that do not have such a system. Therefore, we can affirm that Amana Katu uses a design strategy for product-life extension (Bocken et al., 2016), which is concerned with the extension of the use period of goods through the introduction of loops to extend product life, including reuse, maintenance, and repair. In this case, the 'bombonas' and the water are having their life cycles extended by reuse.

Therefore, the product life-extension design works as a co-creation process, since such a strategy is only possible due to partnerships established with some stakeholders, which generate value for all involved (Evans et al., 2017; Freudenreich et al., 2020).
Based on the system concept and what was described before, it is clear the presence of the principle of reuse in the business model of Amana Katu, in the case of 'bombonas' and water. But there is an important difference among them: the type of cycle each one is associated with. On the one hand, the 'bombona' is part of the technical cycle (Ellen Macarthur Foundation [EMF], 2017), which involves the management of finite material stocks where use replaces consumption. On the other hand, the water is part of the biological cycle (EMF, 2017), which encompasses flows of renewable materials, non-toxic biological materials that can be easily returned to the soil by composting or anaerobic digestion and which mostly regenerate.

Finally, we can also observe the principle of reduction (Ghisellini et al., 2016), that is associated with fewer consumption of resources and generation of waste (Bocken et al., 2016). The use of rainwater implies the elimination of users' need to purchase mineral water, with the consequence of reducing the consumption of this resource and the subsistence costs of the population favored by using the system. Furthermore, the use of 'bombonas' avoids the generation of waste and the need for reverse logistics mechanisms, which, in turn, contributes to the reduction of $\mathrm{CO} 2$ emissions associated with transport in reverse flows. Based on these arguments, our third proposition follows:

Proposition 3: Adoption of circular economy principles in the SBM, and value delivery based on sustainability dimensions, is improved by the cocreation process with stakeholders.

\section{CONCLUSION}

Amana Katu has developed a SBM in the challenging context of Brazilian Amazon. With many difficulties, Amana Katu won competitions, participated in some entrepreneurial programs, and generated results and impact. However, the case showed that without the co-creation process and interaction with a number of stakeholders, the impact could be really different. The role of stakeholders was important in order to co-create a SBM that generates value for all partners and mainly to the beneficiaries.

The Amana Katu SBM was based on aspects such as social mission, community platform, and ecodesign, and these focuses made a positive effect in the success of the initiative. Choosing the correct business model is a difficult activity, and changing the business model for a more adequate, during the process, is not a simple task. Thus, Amana Katu chose a feasible business model and succeeded in communicating its sustainable value proposition to customers and other stakeholders, succeeding in creating and delivering value. 
Amazon represents a major sustainability challenge: as well as being the world's largest remaining tropical forest, it provides locally, regionally, and globally significant human welfare benefits including economic goods (e.g., agricultural products and timber) and non-market ecosystem services, such as climatic regulation and biodiversity conservation. The Amazon biome is home to more than 30 million people, many of them with unmet basic social needs, such as drinkable water. By unraveling the process of co-creating sustainable business models in challenging contexts like this, the research makes contributions to theory and practice.

To theory, this paper contributes for the better understanding of the creation and development of SBMs in challenging contexts. In this kind of context, co-creation processes and a deep relationship with stakeholders have a unique function, and collaborate to create successful initiatives. We can observe exactly this result with Amana Katu's case. This paper also contributes to theory applying SBM patterns, and showing that these patterns can be applied not only to developed countries but also in developing countries with challenging contexts. In addition, we have shown that the SBM patterns have a strong interrelation with some principles of the circular economy. Yet, we contribute with a new theoretical framework that explains the studied phenomena, as well as with the development of three theoretical propositions from the data.

In practical terms, the research describes the formation and development trajectory of Amana Katu, allowing a deeper understanding of motivations, activities, and results existing in this path, something vital to influence future strategic choices on the part of its partners, and serving as benchmark for others social impact businesses.

From the analysis of the case, we can see, for example, that the increase in scalability and diversification of markets can lead Amana Katu to a difficult choice related to the

\section{REFERENCES}

Aragón, L. E. (2013). Amazônia: Conhecer para desenvolver e conservar. Cinco temas para um debate. Sáo Paulo: Hucitec.

Aragón, L. E. \& Clusener-Godt, M. (2003). Problemática do uso local e global da água da Amazônia. Belém: NAEA/ UNESCO.

Bardin, L. (2016). Análise de Conteúdo. São Paulo: Edições 70.

Batista, L., Gong, Y., Pereira, S., Jia, F., \& Bittar, A. (2019). Circular supply chains in emerging economies - A comparative study of packaging recovery ecosystems in China and Brazil. International Journal of Production Research, 57(23), 72487268. https://doi.org/10.1080/00207543.2018.1558295 use of the workforce of at-risk adolescents (NGO Emaús). Considering the influence of this choice on a possible decrease in the social impact of the business model, especially with regard to its ability to contribute to the reduction of poverty, it is important that entrepreneurs think about this possible scenario and look for alternatives to minimize the eventual decreasing of social impact.

Considering that the university stood out as one of the main partners in the development of Amana Katu, we suggest that the initiatives developed are continued and reinforced, so that such institutions (universities) become increasingly active in their respective local innovation ecosystems. This also leads us to suggest that future research should investigate more deeply the role of universities and other teaching/research institutions in building sustainable business models.

We developed the notion of 'SBM patterns combination,' but more about this topic needs to be discussed. Thus, we suggest that future research should investigate more deeply how pattern combination works and its effects on the business model.

Addressing some research limitations, it is important to explain that Amana Katu is a successful SBM in a huge challenging context that needs more sustainable initiatives. Take account that other firms, startups, and SBMs can be investigated in order to understand a more real situation of these businesses in that context. In other words, due to the specificities of the case addressed, the Amana Katu was not compared with other ventures of the same sector, which could allow a more in-depth understanding of the trajectory of SBMs in challenging contexts. Such expansion is relevant even considering Amana Katu as a representative case (Yin, 2014). Therefore, as a single case study, this research has limited power to generalize.

Bocken,N.,Short,S.,Rana,P., \&Evans,S.(2013).Avaluemappingtool for sustainable business modelling. Corporate Governance: The International Journal of Business in Society, 13(5), 482497. https://doi.org/10.1108/CG-06-2013-0078

Bocken, N., Short, S., Rana, P., \& Evans, S. (2014). A literature and practice review to develop sustainable business model archetypes. Journal of Cleaner Production, 65,42-56. https://doi.org/10.1016/j.jclepro.2013.11.039

Bocken, N., Pauw, I., Bakkerd, C., \& Grinten, B. (2016). Product design and business model strategies for a circular economy. Journal of Industrialand Production Engineering, 33(5), 308320. https://doi.org/10.1080/21681015.2016.1172124 
Boons, F., \& Lüdeke-Freund, F. (2013). Business models for sustainable innovation: State-of-the-art and steps towards a research agenda. Journal of Cleaner Production, 45, 9-19. https://doi.org/10.1016/j.jclepro.2012.07.007

Brest, P., \& Bordn, K. (2013). Unpacking the Impact in Impact Investing. Standford Social Innovation Review, 11, 22-27. Retrieved from https://ssir.org/articles/entry/unpacking the impact in impact investing

Chesbrough, H. (2010). Business model innovation: Opportunities and barriers. Long Range Planning, 43(2-3), 354-363. https://doi.org/10.1016/j.lrp.2009.07.010

Choi, D., \& Gray, E. (2008). The venture development processes of "sustainable" entrepreneurs. Management Research News, 31(8), 558-569. https://doi.org/10.1108/01409170810892127

Cohen, B. (2006). Sustainable valley entrepreneurial ecosystems. Business Strategy Environment, 15(1),1-14. https://doi.org/10.1002/bse.428

Cooper, D. R., \& Schindler, P. S. (2016). Métodos de Pesquisa em Administração (12a ed.). Porto Alegre: AMGH.

Dimov, D. (2007). From opportunity insight to opportunity intention: The importance of person-situation learning match. Entrepreneurship Theory \& Practice. 31(4),561583. https://doi.org/10.1111/j.1540-6520.2007.00188.x

Dufays, F., \& Huybrechts, B. (2017). Entrepreneurial teams in social entrepreneurship: When team heterogeneity facilitates organizational hybridity (pp. 273-287). In C. Ben-Hafaïedh \& T. M. Cooney (Eds.), Research handbook on entrepreneurial teams. Cheltenham: Edward Elgar.

Eisenhardt, K. M., \& Graebner, M. E. (2007). Theory building from cases: Opportunities and challenges. Academy of Management Journal, 50(1), 25-32. https://doi.org/10.5465/amj.2007.24160888

Elkington, J. (1994) Towards the sustainable corporation: Winwin-win business strategies for sustainable development. California Management Review, 36, 90-100. Retrieved from https://www.semanticscholar.org/paper/Towards-theSustainable-Corporation\%3A-Win-Win-Win-Elkington/ ee13a5550b3a683923fe66ab36d729fafd135050

Ellen Macarthur Foundation. (2017). Rumo à economia circular: $O$ racional de negócio para acelerar a transição. Retrieved from https://www.ellenmacarthurfoundation.org/assets/ downloads/Rumo-a\%CC\%80-economia-circular Updated 08-12-15.pdf

Evans, S., Vladimirova, D., Holgado, M., Van Fossen, K., Yang, M., Silva, E. A., \& Barlow, C.Y. (2017). Business model innovation for sustainability: Towards a unified perspective for creation of sustainable business models. Business Strategy and the Environment, 26(5), 597-608. https://doi.org/10.1002/bse.1939

Freudenreich, B., Lüdeke-Freund, F., \& Schaltegger, S. (2020). A stakeholder theory perspective on business models: Value creation for sustainability. Journal of Business Ethics, 166, 3-18. https://doi.org/10.1007/s10551-019-04112-z
Geissdoerfer, M, Savaget, P., Bocken, N., \& Hultink, E. J. (2017). The circular economy - A new sustainability paradigm? Journal of Cleaner Production, 143, 757-768. https://doi.org/10.1016/j.jclepro.2016.12.048

Ghisellini, P, Cialani, C., \& Ulgiati, S. (2016). A review on circular economy: The expected transition to a balanced interplay of environmental and economic systems. Journal of Cleaner Production, 114, 1132. https://doi.org/10.1016/j.jclepro.2015.09.007

Ketokivi, M., \& Choi, T. (2014). Renaissance of case research as a scientific method. JournalofOperations Management, 32(5), 232-240. https://doi.org/10.1016/j.jom.2014.03.004

Korhonen, J., Honkasalo, A., \& Seppälä, J. (2018). Circular economy: The concepts and its limitations. Ecological Economics, 143, 37-46. https://doi.org/10.1016/j.ecolecon.2017.06.041

Jabbour, A. B. L. S., Luiz, J. V. R., Luiz, O. R., Jabbour, C. J. C., Ndubisi, N. O., Oliveira, J. H. C. de, \& Horneaux Junior, F. (2019). Circular economy business models and operations management. Journal of Cleaner Production, 235, 15251539. https://doi.org/10.1016/j.jclepro.2019.06.349

Jamali, D., Yianni, M., \&Abdallah, H. (2011). Strategic partnerships, social capital and innovation: Accounting for social alliance innovation. Business Ethics: A European Review, 20(4), $375-$ 391. https://doi.org/10.1111/j.1467-8608.2011.01621.x

Lovejoy, T. E., \& Nobre, C. (2018). Amazon tipping point. Science Advances, 4(2), eaat2340. https://doi.org/10.1126/sciadv.aat2340

Lüdeke-Freund, F. \& Dembek, K. (2017). Sustainable business model research and practice: New field or passing fancy? Journal of Cleaner Production, 168, 1668-1678. https://doi.org/10.1016/j.jclepro.2017.08.093

Lüdeke-Freund, F., Carroux, S., Joyce, A., Massa, L., \& Breuer, H. (2018). The Sustainable Business Model Pattern Taxonomy: 45 patterns to support sustainability-oriented business model innovation. Sustainable Production and Consumption, 15, 145-162. https://doi.org/10.1016/j.spc.2018.06.004

Manning, S., \& Roessler, D. (2014). The formation of crosssector development partnerships: how bridging agents shape project agendas and longer-term alliances. Journal of Business Ethics, 123(3), 527-547. https://doi.org/10.1007/s10551-013-1853-5

Matews, J., \& Tan, H. (2011). Process toward a circular economy in China: The drivers (and inhibitors) of eco-industrial initiative. Journal of Industrial Ecology, 15(3), 435-457. https://doi.org/10.1111/j.1530-9290.2011.00332.x

Murray, A., Skene, K., \& Haynes, K. (2017). The circular economy: an interdisciplinary exploration of the concept and application in a global context. Journal of Business Ethics, 140, 369380. https://doi.org/10.1007/s10551-015-2693-2

Nosratabadi, S., Mosavi, A., Shamshirband, S., Kazimieras Zavadskas, E., Rakotonirainy, A., \& Chau, K. W. (2019). Sustainable business models: A review. Sustainability, 11(6), 1663. https://doi.org/10.3390/su11061663

Patton, M. Q. (2014), Qualitative research \& evaluation methods: Integrating theory and practice. Thousand Oaks, CA: Sage Publications. 
Paulus, T.M., \& Lester, J.N. (2016). ATLAS.ti for conversation and discourse analysis studies. International Journal of Social Research Methodology, 19(4), 405-428. https://doi.org/10.1080/13645579.2015.1021949

Perrini, F., Vurro, C., \& Costanzo, L. A. (2010). A process-based view of social entrepreneurship: From opportunity identification to scaling-up social change in the case of San Patrignano. Entrepreneurship and Regional Development, 22(6), 515534. https://doi.org/10.1080/08985626.2010.488402

Rashid, A. Asif, F. M. Krajnik, P., \& Nicolescu, C. M. (2013). Resource conservative manufacturing: An essential change in business and technology paradigm for sustainable manufacturing. Journal of Cleaner Production, 57, 166177. Retrieved from https://www.tib.eu/en/search/id/ elsevier\%3Adoi $10.1016 \% 252 \mathrm{Fj}$.jclepro.2013.06.012/ Resource-Conservative-Manufacturing-an-essential/

Richardson, J. (2008). The business model: An integrative framework for strategy. Strategic Change, 17(5-6), 133144. https://doi.org/10.2139/ssrn.932998

Schaltegger, S., Lüdeke-Freund, F., \& Hansen, E. (2016). Business models for sustainability: A co-evolutionary analysis of sustainable entrepreneurship, innovation, and transformation. Organization \& Environment, 29(3), 264289. https://doi.org/10.1177/1086026616633272

Sistema Nacional de Informaçóes sobre Saneamento. (2016). Diagnóstico dos serviços de água e esgotos de 2014. Brasília, DF: SNSA/MCIDADES.
Teece, D. (2010). Business models, business strategy and innovation. Long Range Planning, 43, 172-194. https://doi.org/10.1016/j.lrp.2009.07.003

Veloso, N. S. L., \& Mendes, R. L. R. (2014). Aproveitamento da água da chuva na Amazônia: experiências nas ilhas de Belém/PA. Revista Brasileira de Recursos Hidricos, 19(1), 229-242. Retrieved from https://docplayer.com. br/11865459-Aproveitamento-da-agua-da-chuva-naamazonia-experiencias-nas-ilhas-de-belem-pa.html

Wirtz, B. W., Pistoia, A., Ullrich, S., \& Göttel, V. (2016). Business models: Origin, development and future research perspectives. Long Range Planning, 49(1), 36-54. https://doi.org/10.1016/j.Irp.2015.04.001

World Health Organization. (2017). Inheriting a sustainable world? Atlas on children's health and the environment. Geneva: WHO.

World Health Organization. (1986). Ottawa Charter for Health Promotion. New York: World Health Organization. Available at: https:/www.who.int/healthpromotion/ conferences/previous/ottawa/en/

Yin, R. K. (2014). Estudo de Caso: planejamento e métodos (5a ed.). Porto Alegre: Bookman.

Zott, C., Amit, R., \& Massa, L. (2011). The business model: Recent developments and future research. Journal of Management, 37(4), 1019-1042. https://doi.org/10.1177/0149206311406265 


\section{Authorship}

\section{José Augusto Lacerda Fernandes*}

Universidade Federal do Pará, Agência de Inovação Tecnológica (UNIVERSITEC)

R. Augusto Corrêa, no 1, Universitário, 66075-075, Belém, PA, Brazil

E-mail address: lacerda.fernandes@gmail.com

(1) https://orcid.org/0000-0003-4748-1289

\section{José Milton de Sousa-Filho}

Universidade de Fortaleza, Programa de Pós-Graduação em Administração de Empresas

Av. Washington Soares, no 1321, Edson Queiroz, 60.811-905, Fortaleza, CE, Brazil

E-mail address: jalf@ufpa.br

(1) https://orcid.org/0000-0002-3078-3179

\section{Fernando Luiz Emerenciano Viana}

Universidade de Fortaleza, Programa de Pós-Graduaçáo em Administração de Empresas

Av. Washington Soares, no 1321, Edson Queiroz, 60.811-905, Fortaleza, CE, Brazil

E-mail address: fernandoviana@unifor.br

(1) https://orcid.org/0000-0003-0911-7208

* Corresponding Author

\section{Funding}

There are no funders to report for this article.

\section{Conflict of Interests}

The authors have stated that there is no conflict of interest.

\section{Copyrights}

RAC owns the copyright to this content.

\section{Authors' Contributions}

$1^{\text {st }}$ author: conceptualization (equal); data curation (lead); formal analysis (equal); investigation (lead); methodology (equal); visualization (equal); writing - original draft (equal); writing - proofreading and editing (equal).

$2^{\text {nd }}$ author: conceptualization (equal); formal analysis (equal); methodology (equal); visualization (equal); writing - original draft (equal); writing - review \& editing (equal).

$3^{\text {rd }}$ author: conceptualization (equal); formal analysis (equal); methodology (equal); visualization (equal); writing - original draft (equal); writing - review \& editing (equal).

\section{Peer Review Method}

This content was evaluated using the double-blind peer review process. The disclosure of the reviewers' information on the first page, as well as the Peer Review Report, is made only after concluding the evaluation process, and with the voluntary consent of the respective reviewers and authors.

\section{Plagiarism Check}

The RAC maintains the practice of submitting all documents approved for publication to the plagiarism check, using specific tools, e.g.: iThenticate.

\section{Data Availability}

RAC encourages data sharing but, in compliance with ethical principles, it does not demand the disclosure of any means of identifying research subjects, preserving the privacy of research subjects. The practice of open data is to enable the reproducibility of results, and to ensure the unrestricted transparency of the results of the published research, without requiring the identity of research subjects. 


\section{APPENDIX A}

Table A1. Competitions and awards.

\begin{tabular}{|c|c|c|}
\hline Initiative & Year & Result \\
\hline Desafio Inove+ & 2017 & First Place \\
\hline Camp Ecoinovação — Desafio Água & 2018 & Top 10 Finalist \\
\hline Ford C3 Cycle 5 & 2018 & Winner \\
\hline II Prêmio Startup Assemae & 2018 & Winner \\
\hline Prêmio Mútua / Anprotec de Inovação e Empreendedorismo & 2018 & Second Place \\
\hline Enactus Brasil and Amanco SDG 6 Prize & 2018 & Winner \\
\hline Ford Mobility Innovation Challenge & 2018 & First Place \\
\hline World Water Race & 2018 & First Place \\
\hline Accelerator Program AB InBev & 2019 & Finalist \\
\hline Prêmio Nufarm de Consciência e Ética no Agronegócio & 2019 & Winner \\
\hline Prêmio Latinoamérica Verde & 2019 & $\begin{array}{l}\text { Top } 500 \text { (General), Top } 30 \\
\text { (Water Category), Top } 3 \\
\text { (Brazil) }\end{array}$ \\
\hline Enactus Brasil / Amanco / Ford Fund SDG 6 Prize & 2019 & Winner \\
\hline $\begin{array}{l}\text { Competição Global de Ideias de Negócios Verdes - Climate Ventures / Climate } \\
\text { Launchpad }\end{array}$ & 2019 & Winner \\
\hline SDG Action Awards & 2019 & Winner \\
\hline Evento Nacional Enactus Brasil & 2019 & National Champion \\
\hline World Water Race & 2019 & Second Place \\
\hline
\end{tabular}

Note. Research data. 